\title{
Genetic Variability Studies in Sweet Potato (Ipomoea batatas (L.) Lam) Genotypes under Hill Zone of Karnataka, India
}

\author{
M.B. Sharavati ${ }^{*}$, V. Srinivasa, R.B. Anusha and A.S. Shubha \\ Department of vegetable science, College of Horticulture, Mudigere, India \\ University of Agricultural and Horticultural sciences, Shivamogga, Karnataka, India \\ *Corresponding author
}

\begin{tabular}{|c|}
\hline Keywords \\
\hline $\begin{array}{l}\text { Variability, Heritability, } \\
\text { Genotypic coefficient, } \\
\text { Phenotypic coefficient of } \\
\text { variation }\end{array}$ \\
\hline Article Info \\
\hline $\begin{array}{l}\text { Accepted: } \\
08 \text { August } 2018 \\
\text { Available Online: } \\
\text { 10 September } 2018\end{array}$ \\
\hline
\end{tabular}

\section{A B S T R A C T}

The present investigation was undertaken to estimate the genetic variability, heritability and genetic advance for growth and yield parameters among 30 genotypes of sweet potato [Ipomoea batatas (L.) Lam.] in a randomized block design with two replications during rabi 2017-18 at College of Horticulture, Mudigere, Karnataka. Analysis of variance revealed highly significant difference among the genotypes was observed for all the growth and yield parameters. The phenotypic coefficient of variation was higher than genotypic coefficient of variation for all the traits. High (>20\%) genotypic coefficient of variation $(\mathrm{GCV})$ and phenotypic coefficient variation (PCV) were observed for leaf area, tuber weight, dry weight of vine, total tuber yield per vine, total tuber yield per plot and marketable yield per hectare. It indicated the existence of broad genetic base, which would be amenable for further selection. High heritability $(>60 \%)$ coupled with high genetic advance as per cent over mean ( $>20 \%$ ) were recorded for the characters viz., vine length, number of leaves per vine, inter nodal length, vine girth, chlorophyll content, leaf area, tuber length, tuber girth, tuber weight, dry weight of vine, total tuber yield per vine, total tuber yield per plot and marketable yield per hectare indicated that the high heritability is due to additive gene effects which can be utilized for further crop improvement programme.

\section{Introduction}

Sweet potato [Ipomoea batatas (L.) Lam] is a dicotyledonous plant belonging to the family Convolvulaceae is one of such important starchy tuber crops in tropical and subtropical countries because of its yield potential and high calorific value. This family includes 55 genera and more than 1000 species (Watson and Dallwitz, 2000). However, only Ipomoea batatas is of economic importance as a source of food. The amount of variability that exists in the germplasm collections of any crop is of utmost importance towards breeding for better varieties. Particularly, genetic variability for a given character is a basic prerequisite for its improvement by systematic breeding. Sweet potato is a highly heterozygous and crosspollinated crop in which many of the traits show continuous variation. Since it is highly heterozygous, there is extensive variability within the species, which is available for exploitation by plant breeders (Jones et al., 1986). Hence, consideration of quantitative 
approaches for exploitation of the extensive genetic variability available in sweet potato is of utmost importance, which in turn is dependent on good estimates of the genetic parameters. Estimates of genetic parameters serve as a base for selection and hybridization as the degree of variability for a given character is a basic prerequisite for its improvement.

Sweet potato is a cross-pollinated and highly heterozygous crop resulting in large variability. Presence of variability is prerequisite to the plant breeder for planning an effective breeding programme. This is useful for selecting, identifying promising variants for developing hybrids or varieties directly or through recombinant breeding. Genetic analysis reveals the genetic nature of the inheritance of tuber yield and yield components which is required to design efficient sweet potato improvement breeding statergy. Therefore, this research was conducted with the objective to assess the extent and nature of genetic variability and heritability among the sweet potato genotypes.

\section{Materials and Methods}

The experiment was conducted from September, 2017 to January, 2018 at experimental farm of the Department of Vegetable Science, College of Horticulture, Mudigere, University of Agricultural and Horticultural sciences, Shimogga, Karnataka, India. The location is at $13^{\circ} 25^{\prime} \mathrm{N}$ latitude, $75^{\circ} 25^{\prime} \mathrm{E}$ longitude, and $980 \mathrm{~m}$ above mean sea level. The soil was a medium sandy loam. Well matured healthy and disease-free cuttings of thirty genotypes of sweet potatoes (Table 1) were procured from AICRP on Tuber crops, Dharwad, UHS, Bagalkot have been taken for investigation. The experiment was laid out in a randomized complete block design (RCBD) with two replications. The treatments in each replication were allotted randomly by using random number table. Sweet potato cuttings which have 2-3 buds were planted in each replication with $3 \mathrm{~m} \times 2 \mathrm{~m}$ plot size at $60 \mathrm{~cm} \times 30 \mathrm{~cm}$ spacing. All other recommended cultural practices and irrigation were applies as needed. Plots were kept free from weeds by regular hand weeding. Five plants of each genotype from each replication were used for observations.

\section{Statistical analysis}

Analysis of variance was carried out as per the procedure given by Panse and Sukhatme (1957). Phenotypic and genotypic coefficients of variation (PCV and GCV) were computed according to Burton and Devane (1953). Heritability in broad sense was estimated as per Weber and Moorthy (1952). Genetic advance was estimated as per the formula proposed by Johnson et al., (1955). The range of genetic advance as per cent of mean was classified as low (Less than 10\%), moderate (10 - 20\%) and high (more than 20\%) as suggested by Johnson et al., (1955).

\section{Results and Discussion}

The examination of readily available variability in the germplasm of the given species is also an important avenue available for the breeder. The first step in plant breeding programme is to determine the extent of variability for the traits under improvement and to divide this variability into genetic and environmental components.

\section{Analysis of variance (ANOVA)}

The analysis of variance (ANOVA) showed highly significant differences among the genotypes for all the growth and yield component traits viz., vine length, number of axillary branches, number of leaves per vine, inter nodal length, vine girth, leaf area, chlorophyll content, absolute growth rate, crop 
growth rate, relative growth rate, net assimilation rate, fresh weight of vine, number of tubers per vine, tuber length, tuber girth, tuber weight, dry weight of vine, total tuber yield per vine, total tuber yield per plot and marketable yield per hectare (Table 2 and 3). It indicated the existence of broad genetic base, which would be amenable for further selection. These findings are in line with earlier reports of Basavaraj et al., (2005) in potato, Engida et al., (2006) and Shashikanth et al., (2008) in sweet potato.

\section{Phenotypic and genotypic coefficient of} variation

Higher magnitude of PCV (phenotypic coefficient of variation) and GCV (genotypic coefficient of variation) (> 20\%) were observed for leaf area at 45 DAP (53.22 and $50.25 \%$ ), tuber weight (22.04 and $21.36 \%$ ), dry weight of vine (32.45 and $32.00 \%$ ), total tuber yield per vine (31.48 and $30.50 \%)$, total tuber yield per plot (34.76 and $33.89 \%$ ) and marketable yield per hectare (34.73 and 33.86 $\%)$. But high PCV was observed for intermodal length at 90 DAP $(20.80 \%)$.

Therefore, additive component is predominant here. This reveals that influence of the environment for these characters is negligible and the role of the genotypic performance in the full expression of the phenotype. Moderate magnitude of PCV and GCV were observe for vine length at 90 DAP (17.62 and $14.04 \%)$, number of leaves per vine at 90 DAP (18.04 and $14.41 \%$ ), vine girth at 90 DAP (19.50 and $17.68 \%)$, chlorophyll content (17.53 and $17.14 \%)$, fresh weight of vine (12.26 and $10.70 \%)$, number of tubers per vine (16.98 and $11.43 \%$ ), tuber length and tuber girth. But moderate PCV was observed for number of axillary branches at 90 DAP (10.71\%). Whereas, the low magnitude of GCV was observed for number of axillary branches at 90 DAP $(8.01 \%)$ (Table 4 and 5). These results are in accordance with the findings of Sharma (2004) in sweet potato, Basavaraj et al., (2005) in potato and Engida et al., (2006) in sweet potato.

\section{Heritability}

With the genotypic coefficient of variation alone, it is difficult to determine the relative amount of heritable and non- heritable components of variations present in the population. Estimates of heritability and genetic advance would supplement this parameter. Estimate of heritability was recorded high for the characters viz., vine length at 90 DAP $(63.50 \%)$, number of leaves per vine at 90 DAP $(63.81 \%)$, inter nodal length at 90 DAP $(62.73 \%)$, vine girth at 90 DAP (82.2\%), chlorophyll content at 40 DAP $(95.6 \%)$, leaf area at 45 DAP $(89.14 \%)$, fresh weight of vine at 90 DAP $(76.14 \%)$, tuber length $(68.22 \%)$, tuber girth $(78.10 \%)$, tuber weight $(93.94 \%)$, dry weight of vine at 90 DAP (97.20\%), total tuber yield per vine $(93.90 \%)$, total tuber yield per plot $(95.10 \%)$ and marketable yield per hectare $(95.10 \%)$. The moderate heritability was observed for number of axillary branches at 90 DAP (55.94 $\%)$ and number of tubers per vine $(45.30 \%)$ (Table 4 and 5).

The high and moderate heritability recorded for the traits indicated that these characters were less influenced by environmental fluctuations and governed by the additive gene effects that are substantially contributing towards the expression of these traits. Hence, selection for these traits will lead to accumulation of more desirable genotypes. However, rest of the traits seems to be governed by non-additive gene effects. The present findings on heritability are in accordance with findings reported by the various workers viz., Sahu (2003), Teshome et al., (2004), Engida et al., (2006) and Shashikanth et al., (2008) in sweet potato. 
Table.1 List of sweet potato genotypes used for the study

\begin{tabular}{|c|c|c|c|c|c|}
\hline No & Name of the genotype & No & Name of the genotype & No & Name of the genotype \\
\hline $\mathbf{1}$ & BSP-1 & 11 & BSP-13 & 21 & BSP-23 \\
\hline $\mathbf{2}$ & BSP-2 & 12 & BSP-14 & 22 & BSP-24 \\
\hline $\mathbf{3}$ & BSP-3 & 13 & BSP-15 & 23 & BSP-25 \\
\hline $\mathbf{4}$ & BSP-6 & 14 & BSP-16 & 24 & BSP-26 \\
\hline $\mathbf{5}$ & BSP-7 & 15 & BSP-17 & 25 & BSP-27 \\
\hline $\mathbf{6}$ & BSP-8 & 16 & BSP-18 & 26 & BSP-28 \\
\hline $\mathbf{7}$ & BSP-9 & 17 & BSP-19 & 27 & BSP-29 \\
\hline $\mathbf{8}$ & BSP-10 & 18 & BSP-20 & 28 & BSP-30 \\
\hline $\mathbf{9}$ & BSP-11 & 19 & BSP-21 & 29 & Vikram \\
\hline 10 & BSP-12 & 20 & BSP-22 & 30 & Sree Bhadra \\
\hline
\end{tabular}

Table.2 Analysis of variance for growth parameters in sweet potato genotypes

\begin{tabular}{|c|c|c|c|c|c|c|}
\hline SI. & $\begin{array}{c}\text { Source of } \\
\text { variation/characters }\end{array}$ & Replication & $\begin{array}{l}\text { Treatments } \\
\text { (Genotypes) }\end{array}$ & Error & \multirow[t]{2}{*}{ S.Em \pm} & \multirow{2}{*}{$\begin{array}{l}\text { CD @ } \\
5 \%\end{array}$} \\
\hline No. & Degrees of freedom & 1 & 29 & 29 & & \\
\hline & Growth parameters & & & & & \\
\hline 1 & $\begin{array}{l}\text { Vine length }(\mathrm{cm}) \text { at } 90 \\
\text { DAP }\end{array}$ & 1.20 & $1131.63^{* *}$ & 252.3 & 11.23 & 33.00 \\
\hline 2 & $\begin{array}{l}\text { Number of axillary } \\
\text { branches at } 90 \text { DAP }\end{array}$ & 0.37 & $0.337 * *$ & 0.095 & 0.218 & 0.631 \\
\hline 3 & $\begin{array}{l}\text { Number of leaves per vine } \\
\text { at } 90 \text { DAP }\end{array}$ & 54.24 & $1106.34 * *$ & 244.41 & 11.05 & 31.97 \\
\hline 4 & $\begin{array}{l}\text { Chlorophyll content }(\mathrm{mg} / \mathrm{g}) \\
\text { at } 45 \text { DAP }\end{array}$ & 0.01 & $0.16^{* *}$ & 0.0035 & 0.042 & 0.12 \\
\hline 5 & $\begin{array}{l}\text { Inter nodal length }(\mathrm{cm}) \text { at } \\
90 \text { DAP }\end{array}$ & 0.08 & $0.79 * *$ & 0.18 & 0.30 & 0.88 \\
\hline 6 & Vine girth $(\mathrm{cm})$ at 90 DAP & 0.07 & $0.78^{* * *}$ & 0.08 & 0.20 & 0.57 \\
\hline 7 & Leaf area $\left(\mathrm{cm}^{2}\right)$ at 45 DAP & 60201.63 & $691158.86^{* *}$ & 39673.95 & 140.84 & 407.37 \\
\hline 8 & $\begin{array}{l}\text { Absolute Growth Rate } \\
\text { (AGR) (g/plant/day) }\end{array}$ & 0.0026 & $0.0035^{* *}$ & 0.0002 & 0.008 & 0.00257 \\
\hline 9 & $\begin{array}{l}\text { Relative Growth Rate } \\
\text { (RGR) (g/g/day) }\end{array}$ & 0.0000103 & $0.000009 * *$ & 0.00000008 & 0.0002 & 0.0006 \\
\hline 10 & $\begin{array}{l}\text { Crop Growth Rate (CGR) } \\
\text { (g/dm²/day) }\end{array}$ & 0.0017 & $0.0035^{* *}$ & 0.0003 & 0.0118 & 0.0343 \\
\hline 11 & 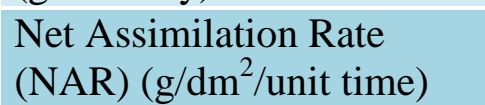 & 0.000000018 & 0.00000001 & 0.00000001 & 0.00007 & 0.00021 \\
\hline 12 & $\begin{array}{l}\text { Fresh weight of vine }(\mathrm{g}) \text { at } \\
90 \text { DAP }\end{array}$ & 217.74 & $401.63 * *$ & 54.32 & 5.21 & 15.07 \\
\hline
\end{tabular}


Int.J.Curr.Microbiol.App.Sci (2018) 7(9): 850-858

Table.3 Analysis of variance for yield parameters in sweet potato genotypes

\begin{tabular}{|c|c|c|c|c|c|c|}
\hline $\begin{array}{l}\text { Sl. } \\
\text { No. }\end{array}$ & $\begin{array}{c}\text { Source of variation/ } \\
\text { characters }\end{array}$ & Replication & $\begin{array}{l}\text { Treatments } \\
\text { (Genotypes) }\end{array}$ & Error & \multirow[t]{2}{*}{ S.Em \pm} & \multirow[t]{2}{*}{$\begin{array}{c}\text { CD@ } \\
5 \%\end{array}$} \\
\hline & Degrees of freedom & 1 & 29 & 29 & & \\
\hline & \multicolumn{6}{|l|}{ Yield parameters } \\
\hline 1 & Number of tubers per vine & 0.04 & $0.37 * *$ & 0.14 & 0.26 & 0.76 \\
\hline 2 & Tuber length $(\mathrm{cm})$ & 0.57 & $9.08 * *$ & 1.71 & 0.93 & 2.68 \\
\hline 3 & Tuber girth $(\mathrm{cm})$ & 7.37 & $18.46 * *$ & 2.27 & 1.06 & 3.08 \\
\hline 4 & Tuber weight (g) & 95.20 & $4080.22 * *$ & 127.59 & 7.98 & 23.10 \\
\hline 5 & Dry weight of vine (g) & 26.30 & $113.82 * *$ & 1.59 & 0.89 & 2.58 \\
\hline 6 & $\begin{array}{l}\text { Total tuber yield per vine } \\
(\mathrm{kg})\end{array}$ & 0.0022 & $0.04 * *$ & 0.0013 & 0.025 & 0.074 \\
\hline 7 & $\begin{array}{l}\text { Total tuber yield per plot } \\
(\mathrm{kg})\end{array}$ & 1.03 & $26.65 * *$ & 0.67 & 0.58 & 1.68 \\
\hline 8 & $\begin{array}{l}\text { Marketable yield per hectare } \\
\text { (tonnes) }\end{array}$ & 3.08 & $73.91 * *$ & 1.87 & 0.97 & 2.79 \\
\hline
\end{tabular}




\section{Int.J.Curr.Microbiol.App.Sci (2018) 7(9): 850-858}

Table.4 Estimate of genetic parameters for growth attributes in sweet potato genotypes

\begin{tabular}{|c|c|c|c|c|c|c|c|c|c|c|}
\hline $\begin{array}{l}\text { Sl. } \\
\text { No. }\end{array}$ & Characters & Mean \pm S.Em & Range & $\mathbf{G V}$ & PV & GCV $(\%)$ & $\begin{array}{l}\mathrm{PCV} \\
(\%)\end{array}$ & $\begin{array}{l}\mathbf{h}^{2} \\
(\%)\end{array}$ & GA & $\begin{array}{l}\text { GAM } \\
(\%)\end{array}$ \\
\hline 1 & $\begin{array}{l}\text { Vine length }(\mathrm{cm}) \text { at } 90 \\
\text { DAP }\end{array}$ & $149.22 \pm 10.53$ & $121.1-215.25$ & 439.51 & 692.11 & 14.04 & 17.62 & 63.5 & 34.41 & 23.06 \\
\hline 2 & $\begin{array}{l}\text { Number of axillary } \\
\text { branches at } 90 \text { DAP }\end{array}$ & $4.35 \pm 0.22$ & $3.50-4.90$ & 0.12 & 0.22 & 8.01 & 10.71 & 55.94 & 0.54 & 12.34 \\
\hline 3 & $\begin{array}{l}\text { Number of leaves per vine } \\
\text { at } 90 \text { DAP }\end{array}$ & $143.99 \pm 11.05$ & $104.43-212.25$ & 430.96 & 675.37 & 14.41 & 18.04 & 63.81 & 34.16 & 23.72 \\
\hline 4 & $\begin{array}{l}\text { Inter nodal length }(\mathrm{cm}) \text { at } \\
90 \text { DAP }\end{array}$ & $3.36 \pm 0.30$ & $2.14-4.70$ & 0.31 & 0.50 & 16.47 & 20.80 & 62.73 & 0.90 & 26.88 \\
\hline 5 & Vine girth $(\mathrm{cm})$ at $90 \mathrm{DAP}$ & $3.37 \pm 0.20$ & $2.14-4.65$ & 0.36 & 0.43 & 17.68 & 19.51 & 82.2 & 1.11 & 33.02 \\
\hline 6 & $\begin{array}{l}\text { Chlorophyll content } \\
(\mathrm{mg} / \mathrm{g})\end{array}$ & $1.62 \pm 0.04$ & $1.14-2.20$ & 0.08 & 0.08 & 17.14 & 17.53 & 95.60 & 0.56 & 34.53 \\
\hline 7 & Leaf area $\left(\mathrm{cm}^{2}\right)$ & $1135.68 \pm 140.84$ & $523.33-3328.15$ & 325743.30 & 365417.19 & 50.25 & 53.22 & 89.14 & 1110.06 & 97.74 \\
\hline 8 & Fresh weight of vine $(\mathrm{g})$ & $123.04 \pm 5.21$ & $100.97-171.15$ & 173.35 & 227.67 & 10.70 & 12.26 & 76.14 & 23.66 & 19.23 \\
\hline
\end{tabular}

DAP- Days After Planting

GCV- Genotypic coefficient of Variation

GV- Genotypic Variance

$\mathrm{h}^{2}$ - Broad sense heritability

PCV- Phenotypic coefficient of Variation

GA- Genetic Advance
PV-Phenotypic Variance

GAM- Genetic Advance as per cent of Mean 


\section{Int.J.Curr.Microbiol.App.Sci (2018) 7(9): 850-858}

Table.5 Estimate of genetic parameters for yield attributes in sweet potato genotypes

\begin{tabular}{|c|c|c|c|c|c|c|c|c|c|c|}
\hline $\begin{array}{l}\text { Sl. } \\
\text { No. }\end{array}$ & Characters & Mean \pm S.Em & Range & GV & PV & $\begin{array}{l}\text { GCV } \\
(\%)\end{array}$ & $\begin{array}{l}\text { PCV } \\
(\%)\end{array}$ & $h^{2}(\%)$ & GA & $\begin{array}{c}\text { GAM } \\
(\%)\end{array}$ \\
\hline 1 & Number of tubers per vine & $2.97 \pm 0.26$ & $2.25-3.80$ & 0.12 & 0.26 & 11.43 & 16.98 & 45.30 & 0.47 & 15.85 \\
\hline 2 & Tuber length $(\mathrm{cm})$ & $11.69 \pm 0.93$ & $7.12-14.83$ & 3.68 & 5.40 & 16.42 & 19.88 & 68.22 & 3.27 & 27.94 \\
\hline 3 & Tuber girth $(\mathrm{cm})$ & $18.46 \pm 1.07$ & $12.86-22.52$ & 8.09 & 10.37 & 15.40 & 17.43 & 78.10 & 5.18 & 28.04 \\
\hline 4 & Tuber weight (g) & $208.06 \pm 7.98$ & $129.35-315.28$ & 1976.31 & 2103.91 & 21.36 & 22.04 & 93.94 & 88.75 & 42.65 \\
\hline 5 & Dry weight of vine (g) & $23.40 \pm 0.89$ & $15.01-53.29$ & 56.11 & 57.70 & 32.00 & 32.45 & 97.20 & 15.21 & 65.02 \\
\hline 6 & $\begin{array}{l}\text { Total tuber yield per vine } \\
(\mathrm{kg})\end{array}$ & $0.47 \pm 0.03$ & $0.18-0.84$ & 0.02 & 0.02 & 30.50 & 31.48 & 93.90 & 0.28 & 60.86 \\
\hline 7 & $\begin{array}{l}\text { Total tuber yield per plot } \\
(\mathrm{kg})\end{array}$ & $10.63 \pm 0.58$ & $4.63-19.99$ & 12.99 & 13.66 & 33.89 & 34.76 & 95.10 & 7.24 & 68.08 \\
\hline 8 & $\begin{array}{l}\text { Marketable yield per } \\
\text { hectare (tonnes) }\end{array}$ & $17.72 \pm 0.97$ & 7.71-33.32 & 36.02 & 37.89 & 33.86 & 34.73 & 95.10 & 12.05 & 68.02 \\
\hline & $\begin{array}{l}\text { DAP- Days After Planting } \\
\text { GCV- Genotypic coefficient of } \\
h^{2}-\text { Broad sense heritability }\end{array}$ & \multicolumn{4}{|c|}{$\begin{array}{l}\text { GV- Genotypic Variance } \\
\text { PCV- Phenotypic coefficient of Variation } \\
\text { GA- Genetic Advance }\end{array}$} & \multicolumn{5}{|c|}{ PV-Phenotypic Variance } \\
\hline
\end{tabular}




\section{Genetic advance as percent over mean}

Genetic advance is important to find out the genetic gains likely to be achieved in the next generation. These are classified as high (> 20 $\%$ ), medium (10 to $20 \%$ ) and low (<10\%). The success of genetic advance under selection mainly depends upon genetic variability, heritability and selection intensity.

In the present study highest estimates of genetic advance as percentage of mean were obtained for characters viz., vine length at 90 DAP $(23.06 \%)$, number of leaves per vine at 90 DAP $(23.72 \%)$, inter nodal length at 90 DAP $(26.88 \%)$, vine girth at 90 DAP (33.02 5), chlorophyll content at 45 DAP (34.53\%), leaf area at 45 DAP (97.74 \%), tuber length $(27.94 \%)$, tuber girth $(28.04 \%)$, tuber weight (42.65\%), dry weight of vine at 90 DAP $(65.02 \%)$, total tuber yield per vine $(60.86$ $\%)$, total tuber yield per plot $(68.08 \%)$ and marketable yield per hectare $(68.02 \%)$. The moderate estimate of genetic advance as percentage of mean were obtained for characters viz., number of axillary branches per vine at 90 DAP (12.34\%), fresh weight of vine at 90 DAP $(19.23 \%)$ and number of tubers per vine $(15.85 \%)$ (Table 4 and 5).

Very often, heritability in broad sense is not the true indicator of inheritance of traits, since only additive component of genetic variance is transferred from generation to generation. Therefore heritability in broad sense may mislead in judging the effectiveness of selection for the trait. Considering heritability in broad sense along with genetic advance over mean may reveal the prevalence of specific components (additive or nonadditive) for the trait more accurately.

In the present study, high heritability coupled with high genetic advance as per cent over mean was recorded for the characters viz., vine length at 90 DAP, number of leaves per vine at 90 DAP, inter nodal length at 90 DAP, vine girth at $90 \mathrm{DAP}$, chlorophyll content at 45 DAP, leaf area at 45 DAP, tuber length, tuber girth, tuber weight, dry weight of vine at 90 DAP, total tuber yield per vine, total tuber yield per plot and marketable yield per hectare. Whereas, moderate coupled with moderate genetic advance as per cent over mean was recorded for characters like number of axillary branches per vine at 90 DAP, number of tubers per vine and high heritability coupled with moderate genetic advance as per cent over mean was recorded for fresh weight of vine at 90 DAP. The above findings indicated that the characters with the high and moderate heritability and genetic advance can be considered for direct selection for improvement. These results are in agreement with the results of Engida et al., (2006), Shashikanth et al., (2008) Madawal et al., (2015), Demelie and Aragao (2016) and Badu et al., (2017) in sweet potato.

\section{Acknowledgement}

All India Co-ordinated Research Project on Vegetables and Tuber crops, ZAHRS, Kumbhapur Farm, Dharwad for supplying germplasm to conduct research.

\section{References}

Badu, M., Asho, P., Patro, T. S. K. and Sasikala, K. 2017. Studies on genetic variability, heritability and genetic advance for growth, yield and quality parameters among orange flesh sweet potato [Ipomoea batatas (L.) Lam.] Genotypes. International Journal of Current Microbiology and Applied Sciences. 6(9): 1894-1903.

Basavaraj, N., Naik, K. R., Naik, K. S. and Gayatri, G. N. 2005. Genetic variability studies in potato (Solanum tuberosum L.). Potato Journal. 32(3-4): 233-256. 
Burton, G. W. and Devane, E. M. 1953. Estimating heritability from replicated clonal material. Agronomy Journal. 45: 478-481.

Demelie, M. and Aragao, A. 2016. Genetic variability of sweet potato on yield and yield related traits at Werer Agricultural Research Center, Ethiopia. Electronic Journal of Plant Breeding. 7(2):88-96.

Engida, T. E. V., Sastry, D. and Dechassa, N. 2006. Correlation and path analysis in sweetpotato and their implications for clonal selection. Journal of Agronomy. 5(3):391-395.

Johnson, H. W., Robinson, H. F. and Comstock, R. S. 1955. Estimation of genetic and environmental variability in soyabean. Agronomy Journal. 41: 314318.

Jones, A., Dukes, P.D. and Schalk, J.M. 1986. Sweet potato breeding, p. 1-35. In: M.J. Basset (Ed.). Breeding of vegetable crops. AVI Publishing Company, Westport, Conn.

Madawal, S. L., Alloli, Madarkhandi, T. B. S. and Narasannavar, A. 2015. Genetic variability study in sweet potato (Ipomoea batatas L.) genotypes. International Journal of Tropical Agriculture. 33(2):274-282.

Panse, V. G. and Sukhatme, P. V., 1957. The application of genetics to plant breeding. IV. The inheritance of quantitative characters and plant breeding. J. Genet., 40:283-302.

Sahu, G.D., 2003. Genetic variability, correlations and path analysis in sweet potato [Ipomoea batatas (L.) Lam.]. M.Sc. (Ag.) thesis, IGAU, Raipur.

Sharma, G.P., 2004. Selection of ideal genotypes from open pollinated seedling population of sweet potato [Ipomoea batatas (L.) Lam.]. M.Sc. (Ag.) thesis, IGAU, Raipur.

Shashikanth, Evoor, P., Madalageri, M. B., Mulge, R. and Gasti, V. D. 2008. Correlation and path analysis studies in sweet potato (Ipomoea batatas (L.) Lam.). Environment and Ecology. 26(1A):422-426.

Teshome, A., D. Veeraragavathatham and Kannan. M. 2004. Genetic divergence for yield and yield contributing characters in sweet potato. Madras Agric. J., 51: 4.-45.

Watson, I. and Dallwitz, M. J. 2000. The family of flowering plants. Descriptors, identification and information reterval. wttp: biodiversity (verified 14 december, 2000)

Weber, C. R. and Moorthy, H. R. 1952. Heritable and non-heritable relationship and variability of oil content and agronomic characters in the $F_{2}$ generation of soybean crosses. Agronomy Journal. 44: 202-209.

\section{How to cite this article:}

Sharavati, M.B., V. Srinivasa, R.B. Anusha and Shubha, A.S. 2018. Genetic Variability Studies in Sweet Potato (Ipomoea batatas (L.) Lam) Genotypes under Hill Zone of Karnataka, India. Int.J.Curr.Microbiol.App.Sci. 7(09): 850-858. doi: https://doi.org/10.20546/ijcmas.2018.709.102 